\title{
Marketing of Acacia Species (Gum Arabic) in Borno State, Nigeria
}

\author{
H. Y. Umar and C. S. Mesike* \\ Rubber Research Institute of Nigeria, P.M.B 1049, Benin City, Edo State, Nigeria
}

KEYWORDS Income Distribution. Market Structure. Gini-Coefficient. Return to Scale

\begin{abstract}
The study examined the income distribution among Acacia spp (gum arabic) marketers in Borno state. Data were collected from 100 gum arabic marketers in 4 local government areas of Borno state through the use of structured questionnaire. Descriptive statistics, Gini-coefficient and regression models were used to analyse the collected data. The result of the analysis revealed that $71 \%$ of the marketers were also farmers of some arable crops, and $64 \%$ of them had 15 years and above experience in the gum Arabic marketing. The Gini-coefficient result showed that the gum arabic market in the state was concentrated and there was high inequality in the income distribution among the gum arabic marketers. The rate of return to scale (RTS) was 1.061, which implies that gum arabic marketing in the study area was in stage 1 of the production function. This means that allocation of resources for the marketing of gum arabic in the state was irrational.
\end{abstract}

\section{INTRODUCTION}

Acacia species commonly known as gum arabic is the exudates obtained from the various species of the genus Acacia (Wuranti 2006). There are about $1100 \mathrm{spp}$ distributed over tropical and sub-tropical areas of Africa, India, Australia and America, however, only Acacia senegal (grade 1) and Acacia seyal (grade 2) yield gum at economic significance (Sean 1997). The optimum conditions for the growth and performance of the plant are excessive heat, high elevation, sandy soils with scarcity of moisture.

The commercial use of gum arabic can be traced back to the year $2000 \mathrm{BC}$, when the Egyptians used it in foods, adhesive and paint industries (Abdul 2002). The wide spread of gum arabic both locally and internationally was first induced by Mr. Palmer, the Governor of the former Northern Province of Nigeria who sent samples of Acacia senegal to the Imperial Institute, London in 1914 for analysis (FDA 2002). Presently, Nigeria is second to Sudan in the world production of gum arabic. The production of gum arabic from the plants is done by wounding it deliberately or accidentally. The gum oozes out and will be ready for collection after 3-4 weeks. Subsequent collections can be done bi-weekly two to three times from the same wound (Abdul 2002; Abdullahi 2004). Production of gum Arabic in Nigeria is largely from the wild (Olegbe 1998;

*Corresponding Author:

E-mail: sammesike@yahoo.ca
Abdullahi 2004), however, much efforts are made in the gum arabic growing states in the country to establish gum arabic plantation at large scale. The states include Borno, Yobe, Jigawa, Taraba, Adamawa, Zamfara, Kebbi, Gombe and Bauchi. The plant matures and ready for tapping 4 years after planting. There was a total of $1,625.75$ ha private owned gum arabic plantation, $9,766.5$ ha private owned and about 2,449,000 ha of gum Arabic forest reserve in Nigeria (NAGAPPEN 2004). According to Umar (2006), it was reported that gum arabic is on the tremendous increase worldwide. Though, the major determinant of the production of any industrial crop is its demand and the revenue derived from it. That is, the better the market situation of a crop, the more the desire for higher production among farmers. This paper therefore seeks to examine the market structure of Acacia species in Borno state with reference to product concentration in the market, income distribution and return to scale on gum arabic marketing.

\section{METHODOLOGY}

Four (4) Local Government Areas in Borno State were purposively sampled for survey to examine the gum arabic market structure. These were Maiduguri, Bama, Gwoza and Konduga Local Government Areas (LGAs). Data were collected through the use of structured questionnaire. One hundred and twenty copies of questionnaire were randomly administered on gum arabic marketers in the four LGAs, out of which one hundred were 
retrieved and used for this study. A total of 30 gum arabic marketers each from Maiduguri and Bama that were randomly interviewed were considered; while 28 and 12 were also filled correctly and considered from Konduga and Gwoza LGAs respectively. The data were analyzed using descriptive statistics, Gini-coefficient and regression models.

\section{RESULTS AND DISCUSSION}

Age Distribution of the Respondents: The result shows that people between the ages of 3150 years participated more in the marketing of gum arabic in the state (Table 1). The least participants were those between the ages of 30 years and below as well as those above 60 years with $6 \%$ level of participation. This implies that people within the ages of 31-50 years were more dynamic and willing to take risk associated with gum arabic marketing in the state. This study agrees with the work of Groh et al (2004) that people between the ages of 30 to 50 provide $90 \%$ of farm labour in Nigeria.

Major Occupational Distribution of the Respondents: Table 1 also shows that $71 \%$ of the respondents were gum arabic marketers as well as farmers. Only $14 \%$ is reported to be gum arabic marketers only; while $12 \%$ were marketers of gum arabic and other items. It is also indicated that $3 \%$ of the respondents were civil servants.

Majority of the respondents were marketers of gum arabic as well as farmers of arable crops. This implies that marketing of gum arabic is seasonal, and the peak of it does not coincide with farming season in the state. Farmers of arable crops complete the regular farming operations between September and October each year, while the peak of gum arabic marketing starts from December to March each year. This translates to higher income and hence enhances their standard of living.

Gum Arabic Marketing Experience: The study revealed that $64 \%$ of the marketers had 15 years and above marketing experience; while $24 \%$ lie within 10-14 years of experience. The remaining $12 \%$ of the respondents had between 1-9 years experience of the gum arabic marketing (Table 2). This implies that marketing of gum arabic in the state has been in practice for a long time and ought to have been contributing to source of income to many families. This is line with the study of John and Gilles (2002) who stated that gum arabic is an integral part of life in the Sahelian part Africa as majority of the rural dwellers are either gum arabic collectors, producers, rural merchants or exporters.

Source of Capital of the Respondents: The source of capital for the gum arabic marketers is presented in Table 3 . The result shows that only $4 \%$ of the respondents got their capital through formal source while the majority $(96 \%)$ got their capital through informal sources. This implies that the major sources of capital for gum arabic marketing in Borno State were from associations and friends/relatives. It also indicates that banks and government are not giving adequate support to gum arabic marketers despite high revenue generation obtained from the crop in the state. This might also be that gum arabic marketing is monopolized by international merchants that give cash in advance to market agents.

Gumarabic Marketing Out Let in Borno State: Table 3 also presents the marketing out let of gum arabic in the state. The result indicates that cooperative buyers dominated the gum arabic market by $80 \%$, while $20 \%$ of the respondents were independent buyers of gum arabic. This implies that there were certain group of dealers and companies that monopolized the market of gum arabic in the state. Consequently, this imposed a danger to easy entry into the gum

Table 2: Gum arabic marketing experience of the marketers in Borno State

\begin{tabular}{lr}
\hline Years of experience & $\%$ \\
\hline $1-9$ & 12.00 \\
$10-14$ & 24.00 \\
15 and above & 64.00 \\
\hline Total & 100.00 \\
\hline
\end{tabular}

Table 1: Age and occupational distribution of the gum arabic marketers in Borno State

\begin{tabular}{lrlr}
\hline Age (year) & $\%$ & Major occupation & $\%$ \\
\hline 30 and below & 6.00 & Gum Arabic marketing only & 14.00 \\
$31-50$ & 70.00 & Gum Arabic marketing + Farming & 71.00 \\
$51-60$ & 18.00 & Gum Arabic marketing + other items & 12.00 \\
Above 60 & 6.00 & Civil Servant & 3.00 \\
\hline Total & 100.00 & Total & 100.00 \\
\hline
\end{tabular}


Table 3: Source of capital of the gum arabic marketer and the marketing outlet in Borno State

\begin{tabular}{lrrrr}
\hline & Source of Capital & & \multicolumn{2}{c}{ Marketing out let } \\
Types & $\%$ & & Mode of operation & \% \\
\hline Formal & 4.00 & & Independent marketer & 20.00 \\
Informal & 96.00 & & Cooperative marketer & 80.00 \\
\hline Total & 100.00 & Total & 100.00 \\
\hline
\end{tabular}

arabic market in the state. The study also revealed that most of these companies that dominated the market of gum arabic are foreign companies. They export unprocessed gum. This implies that the indigenous companies are deprived of sufficient raw materials, while the country is deprived of value added after processing of the gum, hence lesser revenue generation to the country.

Market Structure Analysis of Gum Arabic in Borno State: Table 4 depicts the market structure analysis of gum arabic in Borno state. The result shows that marketers within the sales range of $\mathrm{N} 1.00$ - N200, 000 constituted $63 \%$ of the total respondents, and this accounted for only $15.3 \%$ proportion of the total sales of gum arabic in the state. The marketers within the sales range of N200, $001-\mathrm{N} 400,000$ was $7 \%$ and they contributed $5 \%$ proportion on the total sales of gum arabic in the state. Those that have the sales of N800, $000-\mathrm{N} 1$ million constituted $18 \%$ of the marketers' population; and their contribution to the total sales was $45 \%$. There were also $12 \%$ of the marketers that had the sales range of greater than N1 million; and their impact on total sales of gum arabic in the state was $35 \%$. The study thus revealed that majority of the marketers $(63 \%)$ had little capital for running the gum arabic business, hence could only show an impact of $15.3 \%$ proportion on the total sales of gum arabic in the state; while marketers of $18 \%$ with sales range of $\mathrm{N} 800,000 \mathrm{~m}-\mathrm{N} 1$ dominated the gum arabic market in the state by $45 \%$ proportion of the total quantity of gum arabic sold in the state. The Gini coefficient calculated was 0.652 . This clearly revealed that there was inequality of income distribution among the gum arabic marketers in Borno State.

Marketing Function Analysis: Double log regression analysis was used to determine the marketing performance of gum arabic in the study area. The explicit production function was $\mathrm{Y}=-0.048+0.004-0.019+0.003+0.141 *-0.050$

$(0.180)(0.023)(0.036)(0.045)(0.055)(0.056)$ $+0.612 *+0.148 *$

(0.058) (0.048)

$\mathrm{R}^{2}=0.985$ standard error $=0.061 \mathrm{~F}$ - value $=808.22 *$ significant at $1 \%$

The timated $\mathrm{R}^{2}$ value of 0.985 implies that the postulated regressors explained $98.5 \%$ of the variation in the regressand while the F-value indicated that all the variables used were involved in the gum arabic marketing. The result also shows that three variables had significant impact on the gum arabic marketing in the state. These factors are type of marketing operation (0.141), purchasing cost (0.612) and other operating expenses (0.418). This implies that a unit increase in each of these variables will lead to an increase in the quantity of gum arabic sold by the value of the coefficient of each variable.

Elasticity of Production and Returns to Scale (RTS): The rate of return to scale (RTS) of the marketing functions was 1.061 (Table 5). This implies that marketing of gum arabic in the state was in stage 1 of the marketing function; and it thus revealed that resources allocation were irrational. On the other hand, it implies that adequate allocation of more resources in the

Table 4: Market structure analysis of gum arabic in Borno State

\begin{tabular}{lrcccccc}
\hline Sales $(N)$ & $\begin{array}{c}\text { No of } \\
\text { sellers }\end{array}$ & $\begin{array}{c}\text { Prop. of } \\
\text { sales }(X)\end{array}$ & $\begin{array}{c}\text { Cumm. Prop. } \\
\text { of sellers }\end{array}$ & $\begin{array}{c}\text { Total value } \\
\text { of sales (N) }\end{array}$ & $\begin{array}{c}\text { Prop, on } \\
\text { total sales }\end{array}$ & $\begin{array}{c}\text { Cumm.Prop. } \\
\text { OnTotal } \\
\text { sales }(Y)\end{array}$ & $X Y$ \\
\hline $1-200,000$ & 63 & 0.63 & 0.63 & 5491486 & 0.153 & 0.153 & 0.096 \\
$200,001-400,000$ & 7 & 0.07 & 0.70 & 1804614 & 0.05 & 0.203 & 0.014 \\
$800,000-1 \mathrm{M}$ & 18 & 0.18 & 0.88 & 1614191 & 0.450 & 0.653 & 0.118 \\
$>1 \mathrm{M}$ & 12 & 0.12 & 1.00 & 12523109 & 0.350 & 1.00 & 0.12 \\
\hline Total & 100.00 & 1.00 & 1.00 & $35,960,500$ & 1.00 & 1.00 & 0.348 \\
\hline
\end{tabular}

Gini - coefficient $=1-$ åxy, but åxy $=0.348 . \quad$ Gini-coefficient $=1-0.348=0.652$ 
Table 5: Coefficient of regression analysis for determining the gum arabic marketing performance.

\begin{tabular}{lcrr}
\hline Variable names & Coefficient & Standard error & $T$ \\
\hline 1. Constant & -1.076 & 0.161 & 6.669 \\
2. Age of marketing (yrs) & -0.048 & 0.108 & 0.442 \\
3. Educational level & 0.004 & 0.023 & 0.182 \\
4. Household size & -0.019 & 0.036 & -0.518 \\
5. Marketing experience (yrs) & 0.003 & 0.045 & 0.689 \\
6. Type of marketing operation & 0.141 & 0.055 & $2.535^{*}$ \\
7. Labour cost (N) & 0.050 & 0.036 & 1.390 \\
8. Other operating expenses (N) & 0.612 & 0.058 & $1.494^{*}$ \\
9. Purchasing cost (N) & 0.418 & 0.048 & $8.686^{*}$ \\
Elasticity of Production & 1.061 & & \\
\hline
\end{tabular}

Note: Elasticity of production: sum of coefficient of variables 2 to 9 .

marketing of gum arabic in the state will result to an increase in the quantity of gum arabic sold and more revenue in Borno State.

\section{CONCLUSION}

The study examined the market structure of gum arabic in Borno State. It is indicated that gum arabic marketing in the state is long been practiced as $64 \%$ of the respondents had $15 \mathrm{yrs}$ and above experience in the business. The result also revealed that there was high inequality in income distribution among the gum arabic marketers in the state. It is also discovered that gum arabic market in Borno State is dominated by cooperative marketers.

\section{REFERENCES}

Abubarkar A 2004. Gum Arabic; Maiden Edition: Reports on Survey of Selected Agricultural Raw Materials in Nigeria. Published by Raw Material Research and Development Council, October, 2004.

Abdul S 2002. Production and Commercialization of Gum Arabic in Sudan. File: // A! / Commercial production of gum. Htm.

FDA 2002. Baseline Survey on Gum Arabic. A Report. Federal Department of Agriculture, Abuja, July 2002.
FDA 2005.Training Manual on Gum Arabic Production Workshop. Federal Department of Agriculture, Abuja, October 18-20, 2005.

Giroh DY, Wuranti V, Abolagba EO, Umar HY 2006. Analysis of the Productivity of Rubber Tappers in the Rubber Belt of Nigeria. Journal of Sustainable Tropical Agriculture Research, 20: 31-36.

John M, Gilles M 2002. The Prospects and Constraints of Development of Gum Arabic in Sub-Saharan Africa. A Document based on available Literatures and Field Trips to Chad, Mali and Niger. A World Bank Project, October 2002.

NAGAPPEN 2002. Best practice, best market. Workshop paper on training the Nigerian gum arabic producer and small trader. Published by Importer Service Corporation, Jersey City, New Jersey, September 2002 USA.

Olegbe PE 1998. production and management of gum arabic in Sudan and sahelian zones of Nigeria. Journal of Agriculture, 1(2): 257- 266.

Sean G 1997. The Sudan Foundation. An occasional paper published by the Sudan Foundation 212 London WC IV 9 LD UK.

Umar HY 2006. Economic Analysis of Gum Arabic Marketing in Nigeria (A Case Study of Borno State). M.Sc Thesis (Unpublished), Department of Agricultural Economics and Extension, Federal University of Technology, Akure.

Wuranti V 2006. Production of Gum Arabic in Yobe State, Nigeria. M.Sc Thesis (Unpublished), Department of Agricultural Economics and Extension, Federal University of Technology, Akure. 